\title{
Turkish Glossary Production and Meaning in the Inherit of Turkish Culture: Comparative Analysis of Seventeen Turkish Language Dictionaries ${ }^{1}$
}

\section{Mustafa BIYIKLI ${ }^{2}$}

\begin{abstract}
Words, therefore glossaries, dictionaries are the memories, identities, vocabularies and culture treasures of nations. Nations produces vocabularies that have been the nations who have protected their cultural heritage, national identity and territorial integrity. All of the Turkish world and notably Anatolia, have been affected by other cultures, civilizations and languages as a result of interaction between the nations and cultures throughout the historical experiences. In this study, the main words in 17 dictionaries were handled one by one within the scope and degree of cultural interaction. The words in 17 glossaries and dictionaries, which are including the Ottoman Turkish and Republican Turkish have been analyzed, classified and made inferences according to the stems of words and the languages they have written by different authors. After a long and exhausting study; The distribution of words according to the languages, the number of words in dictionaries, the origins of words and their numbers and apart from these, the percentage of words coming from different languages in dictionaries and among these percentages the number of Turkish words and their proportion have been exhibited in tables and graphics with numbers.
\end{abstract}

Key Words: Dictionaries in Ottoman Turkish, Turkish Dictionaries, unity of language, national culture, Turkish World

Türk Kültür Mirasında Türkçe’de Sözlük Üretimi ve Anlamı: On yedi Türkçe Sözlüğün Karşılaştırmalı Analizi

$\ddot{O} z$

Kelimeler, dolayısıyla, sözlükler bir milletin hafızasıdır, kimliğidir, dağarcığıdır ve kültür birikimidir. Zengin bir sözlüğe ve kelime hazinesine sahip milletler, kültür ve irfan birikimlerini koruyan, birlik ve bütünlüklerini pekiştiren milletler, tolumlar olmuşlardır. Başta Türkiye olmak üzere Türk Dili konuşan ülkeler ve dolayısıyla Türkçe, tarihi süreci içinde medeniyetler arası, milletlerarası ve kültürlerarası etkileşimler neticesi doğal olarak diğer kültür, medeniyet ve dolayısıyla dillerden etkilenmiştir. Bu çalışmada, söz konusu kültürel etkileşim derecesi ve çerçevesinde 17 adet lügat/sözlükteki ana kelimeler tek tek ele alındı. Osmanlı Türkçesi ve Cumhuriyet Türkçesini içeren 17 lügat/sözlükteki kelimeler, geldikleri kökler ve etkilendikleri diller itibarılyla analiz ve tasnif edildi ve elde edilen verilerle bir sonuca varıldı. Uzun ve yorucu bir çalışmanın sonucu; kelimelerin dillere göre adedi, dağılımı, sözlüklerde toplam kaç ana kelime yer aldığı ve kaç adet kelimenin kökünün hangi dilden geldiğinin yanı sıra, bu değişik dil köklerinden gelen kelimelerin lügâtlerdeki yüzdelik oranları ve bu oranlar arasında Türkçe kökenli kelimelerin adedi ve oranı tablolar ve grafikler halinde rakamlarla gösterildi.

Anabtar Kelimeler: Osmanlıca Lügatler, Türkçe Sözlükler, dil birliği, milli kültür, Türk Dünyası

\section{Atıf İçin / Please Cite As:}

Biylklı, M. (2020). Turkish glossary production and meaning in the inherit of Turkish culture: Comparative analysis of seventeen Turkish language dictionaries. Manas Sosyal Arasttrmalar Dergisi, 9(4), 2051-2066.

Geliş Tarihi / Received Date: 05.04.2019

Kabul Tarihi / Accepted Date: 30.07.2020

\footnotetext{
${ }^{1}$ The summary of this article is presented as a paper in this symposium: V. European Conference on Social and Behavioral Sciences, IASSR - International Association of Social Science Research, St Petersburg, Russia, September 11-14, 2014.

2 Instructor - Kutahya Dumlupinar University Department of History, mustafa.biyikli@dpu.edu.tr

ORCID: 0000-0003-2614-4638
} 


\section{Beginnings and Background}

Ottoman Turkish and Ottoman Paleography are the basic, technical and supplementary courses and branches of, especially, history, political history, economical history, international relations, diplomatical history and literature departments. Thus, when Ottoman Turkish taken into consideration, Ottoman dictionaries and glossaries, which are the bedside books, are directly concerned with the researches, instructors and students of the areas of history, political history, economical history, international relations, diplomatical history and literature.

As well as words, prosodies, plurals, word phrases of Ottoman Turkish and modern Turkish, these issues have been the topic of interest in our dictionaries and glossaries which have arisen as a result of the interaction and accumulation of civilizations, cultures and languages: how many main words are there from the origins of each of other languages, number and percentages of these words, the position, number and percentage of main Turkish words among these.

Because of this, all the primary entry/main words in each of 17 dictionaries/glossaries, which were examined in this work, have been counted according to their origins, examined, and through being classified according to their origins comparatively analyzed. Compound words and word phrases, which have been derived from primary entries/main words have not been taken into consideration and counted.

The number of words in Ottoman glossaries and Turkish dictionaries, their positions according to origins, percentages and the number of words, which have Turkish origins among the words which have origins in other languages and their percentages have been exhibited with tables and graphics in a comparative way.

Because of the plenty of Arabic and Persian words in Ottoman Glossaries and in order to get clear results, Ottoman-Turkish dictionaries and Turkish words have been examined in two groups as Ottoman Glossaries and Turkish Dictionaries.

Eventually, the content of all Ottoman glossaries and Turkish Dictionaries, the number of words according to languages and their proportional distribution, the proportion of Turkish and other words, have been exhibited with tables and graphics clearly. So, it is possible to see the word contents of glossaries and dictionaries through looking at the tables and graphics.

Apart from these, proportional distribution of main words in Ottoman glossaries and, in these glossaries, the proportion of Turkish words to the words which have origins in other languages; the proportional distribution of all main Words in Turkish dictionaries and the proportion of Turkish words in these glossaries to other words and the proportion and distribution of all words in Ottoman glossaries and Turkish dictionaries and the proportion of Turkish words to other words have been exhibited clearly in tables and graphics.

It is important to state that, many of the words, which are in glossaries, have forgotten origins and originated from other languages, emerge as words transformed into Turkish and used in Turkish popularly and legitimately. Their meanings are being understood. Since we have exhibited the proportions of the origins of only the main words, it is important to evaluate the results of the graphics by taking this point into consideration.

However, in the context of the words transformed into Turkish, the words, which are used widely and legitimately through understanding their meanings, it not possible to say the same thing for the words, which have entered to Turkish mainly and mostly from French and other western languages.

In this process, as a result of the relationship between eastern countries, while the eastern languages have been affected from each other, a word stream has occurred primarily and heavily from east to west and these eastern-origined words have transformed into western identity. Thus, western languages have been enriched. In the same way, especially starting from the second half of 19th century, a Word stream has been occurred in technological, philosophical and scientific areas. Thus, all the languages have been formed as compounded elements in the history. For example, English and French as the richest language in the world since they have turned into the languages compounded from various elements.

When the Ottoman glossaries and Turkish dictionaries, which have been examined, are analyzed, the thesaurus of Turkish language in 19th century is very rich and $90 \%$ of the words that entered to Turkish language and literature from other languages has transformed into Turkish and has been popular and 
legitimate. When the native and foreign studies are examined, it is pointed out that the number of Turkish words and the words that have been transformed into Turkish is approximately 100.000.

The process of Turkish-Arab relations (751), and over the 1000-years interactions from politically and socially produces lots of cultural means. The political dominance of Turks in Arab World that started with Tulunids, the dominance of Seljukids on Persians and Ottomans on Arabs have to been taken into consideration in language and culture interaction.

Ottoman Empire, which was founded by Turks from Kay1 Tribe of Central Asia has dominated, governed and affected nearly 60 countries in its history lasting 600 years and have been in cultural interaction and connection in the lengths.

Middle East, Caucasus and Balkans, which are the geo-cultural centers of Islamic World, have been the center of cultural interaction for world states and nations when they were in Ottoman domination and authority. Thus, it is inevitable that as a result of Seljuk and Ottoman domination Arabic and Persian languages have been more visible in the glossaries.

Nevertheless, starting from the Tanzimat Period, the discussions, purification efforts on Turkish and the efforts of elimination of the words that originates from other languages and have transformed into Turkish, or not, from Turkish have reduced the number of words in Turkish to approximately 20.000. Deliberately or not, all the Arabic and Persian words have been eliminated from the books published by Turkish Ministry of Education of today.

However, the words from western languages, especially French words that have not transformed into Turkish have met the requirement of word in Turkish language. It seems that this case reflects to street from language and brings about the problems and discussions on alienation from culture and language.

The distribution of words according to the languages, the number of words in dictionaries, the origins of words and their numbers, and apart from these, the percentage of words coming from different languages in dictionaries and among these percentages the number of Turkish words and their proportion in Turkish Dictionaries have been exhibited in the tables below.

In this respect, in this work, 10 of Ottoman glossaries among the Ottoman glossaries that have been published and 7 Turkish dictionaries were presented through examining and analyzing.

\section{Turkish Dictionary}

Turkish Dictionary, which was prepared by Şemseddin Sami includes of 1574 pages and contains 29038 main words. (Şemseddin Sami, 1901).

The Number of Words and Their Percentage in Turkish Dictionary

Table 1. Numerical Distribution of Words According to Origins

\begin{tabular}{|c|c|c|c|c|c|c|c|c|c|c|}
\hline Turkish & Arabic & Persian & Italian & French & Romaic & Greek & Latin & English & German & $\begin{array}{c}\text { Total Number } \\
\text { of Words }\end{array}$ \\
\hline 13202 & 11123 & 3904 & 300 & 258 & 109 & 95 & 27 & 13 & 7 & 29038 \\
\hline \multirow{2}{*}{\multicolumn{11}{|c|}{$\frac{\text { Total of Western Languages: } 809(\% 3)}{\text { Other Languages }}$}} \\
\hline & & & & & & & & & & \\
\hline \multicolumn{4}{|c|}{13202} & & \multicolumn{6}{|c|}{15836} \\
\hline \multicolumn{4}{|c|}{$\% 46$} & & \multicolumn{6}{|c|}{$\% 54$} \\
\hline
\end{tabular}

In Turkish Dictionary, which is composed of 29038 main words, $46 \%$ (13202) of the words are Turkish originated, 38\% (11123) are Arabic originated, \%13 (3904) are Persian originated and 3\% (809) are western originated. Totally, $46 \%$ (13202) of the words in dictionary are Turkish originated, and 54\% (15836) of them are originated from other languages. 


\section{Dictionary of Naci}

Dictionary of Naci that was prepared by Muallim Naci that consists of 960 pages and includes 18917 main words. Muallim Naci died before completing his work. He could write up to the word "fetva".His work is composed of 832 pages. In that form, it was pressed in 1901 (1317). Müstecebzade İsmet completed the work starting from the word "fetva" based on the notes of Muallim Naci in İstanbul and published in 1906 (1319) (Muallim Naci, 1901, 1906, 1987).

The Number of Words and Their Percentage in Dictionary of Naci

Table 2. Numerical Distribution of Words According to Origins

\begin{tabular}{|c|c|c|c|c|c|c|c|}
\hline Arabic & Persian & Turkish & French & Romaic & Greek & Italian & $\begin{array}{c}\text { Total } \\
\text { Number of Words } \\
\end{array}$ \\
\hline 10856 & 6926 & 492 & 197 & 194 & 127 & 125 & 18917 \\
\hline$\% 57$ & $\% 37$ & $\% 3$ & \multicolumn{4}{|c|}{ Total of Western Languages: 643 (\%3) } & \\
\hline \multicolumn{3}{|c|}{ Turkish } & \multicolumn{5}{|c|}{ Other Languages } \\
\hline \multicolumn{3}{|c|}{492} & \multicolumn{5}{|c|}{18425} \\
\hline \multicolumn{3}{|c|}{$\% 3$} & \multicolumn{5}{|c|}{$\% 997$} \\
\hline
\end{tabular}

In Dictionary of Naci which is composed of 18917 main words \%3 (492) of the words are Turkish originated, \%57 (10856) are Arabic originated, \%37 (6926) are Persian originated and \%3 (643) are western originated. Totally, \%3 (492) of the words in dictionary are Turkish originated, and \%97 (18425) of them are originated from other languages.

\section{Excellent Ottoman Dictionary}

Excellent Ottoman Dictionary, which was prepared by the assistant head of Grand School of Administrative Sciences and Examiner of Internal Press Reşad consists of 999 pages and includes 19731 main words. The dictionary was published in 1319 (1903) with the permit of Ministry of Education dated 10 Teşrin-i Sani 1315 (22th November 1899) (Ali Nazîma-Reşâd, 1319/1903).

The Number of Words and their Percentage in Excellent Ottoman Dictionary

Table 3. Numerical Distribution of Words According to Origins

\begin{tabular}{|c|c|c|c|c|c|}
\hline Arabic & Persian & Greek & Romaic & Syriac & $\begin{array}{c}\text { Total } \\
\text { Number of Words }\end{array}$ \\
\hline 15178 & 4540 & 7 & 3 & 3 & 19731 \\
\hline$\% 77$ & $\% 23$ & \multicolumn{3}{|c|}{$\frac{\text { Total of Western Languages: } 13(\% 0)}{\text { Other Languages }}$} & \\
\hline & Turkish & & \multicolumn{3}{|c|}{ Other Languages } \\
\hline & 0 & & \multicolumn{3}{|c|}{19731} \\
\hline & $\% 0$ & & \multicolumn{3}{|c|}{$\% 100$} \\
\hline
\end{tabular}

In Excellent Ottoman Dictionary, which is composed of 19731 main words \%77 (15178) of the words are Arabic originated, \%23 (4540) are Persian originated and \%0 (13) are western originated. Totally, $\% 0$ of the words in dictionary are Turkish originated, and \%100 (19731) of them are originated from other languages.

\section{Illustrated Ottoman Dictionary}

Illustrated Ottoman Dictionary, which was prepared by Ali Seydi Bey, is composed of 3 volumes and 1132 pages. The dictionary is designed in three columns in each page and 3000 illustrations were used in descriptions of words. The dictionary includes 21316 main words. Ali Seydi Bey, writer of Illustrated Ottoman Dictionary, is among the writers and administrators of late Ottoman period who is mostly known with the dictionaries and history books he wrote for schools. Ali Seydi Bey is a multifaceted figure who has many works on dictionaries, language, history, ethic and a book, namely Our Protocol and Organization and articles published in various newspapers. (Ali Seydî, 1324/1908). 
The Number of Words and their Percentage in Illustrated Ottoman Dictionary

Table 4. Numerical Distribution of Words According to Origins

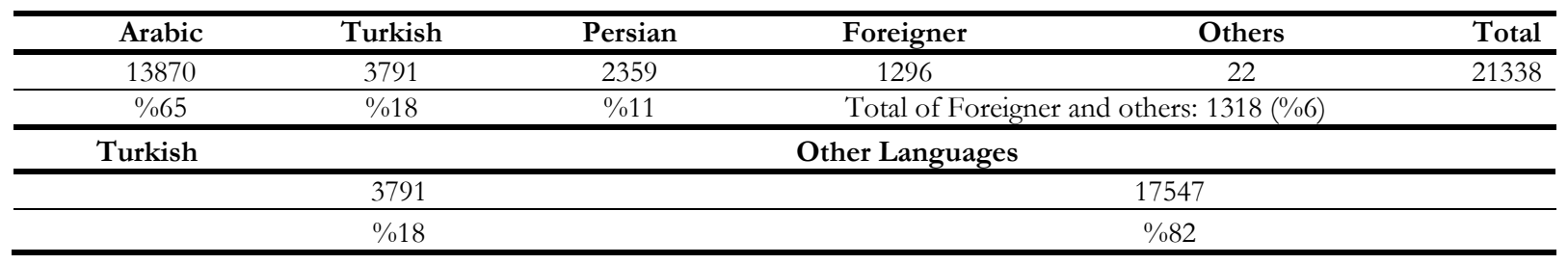

In Illustrated Ottoman Dictionary which is composed of 21316 main words \%18 (3791) of the words are Turkish originated, \%65 (13870) are Arabic originated, \%11 (2359) are Persian originated and \%6 (1318) are western originated. Totally, \%18 (3791) of the words in dictionary are Turkish originated, and $\% 82$ (17547) of them are originated from other languages.

\section{Excellent Ottoman Dictionary}

Excellent Ottoman Dictionary was prepared by Ahmet Rasim. The dictionary, which is composed of 948 pages includes 9950 main words. Approximately half of the dictionary, which is 485 pages is supported with the explanatory illustrations near the words. (Ahmet Rasim, t.y.).

The Number of Words and Their Percentage in Excellent Ottoman Dictionary

Table 5. Numerical Distribution of Words According to Origins

\begin{tabular}{|c|c|c|c|c|c|}
\hline Arabic & Persian & French & Italian & Greek & Hungarian \\
\hline 7560 & 1996 & 165 & 103 & 53 & 32 \\
\hline English & Latin & Albanese & Syriac & Hebrew & Total \\
\hline 22 & 15 & 2 & 1 & 1 & 9950 \\
\hline Arabic & \multicolumn{2}{|r|}{ Persian } & \multicolumn{3}{|c|}{ Total of Western Languages } \\
\hline 7560 & \multicolumn{2}{|r|}{1996} & \multicolumn{3}{|c|}{394} \\
\hline$\% 76$ & \multicolumn{2}{|r|}{$\% 20$} & \multicolumn{3}{|c|}{$\% 4$} \\
\hline \multicolumn{3}{|c|}{ Turkish } & \multicolumn{3}{|c|}{ Other Languages } \\
\hline \multicolumn{3}{|c|}{0} & \multicolumn{3}{|c|}{9950} \\
\hline \multicolumn{3}{|c|}{$\% 0$} & \multicolumn{3}{|c|}{$\% 100$} \\
\hline
\end{tabular}

In Excellent Ottoman Dictionary, which is composed of 9950 main words \%76 (7560) of the words are Arabic originated, \%20 (1996) are Persian originated and \%4 (394) are western originated. Totally, \%0 of the words in dictionary are Turkish originated, and \%100 (9950) of them are originated from other languages.

\section{Turkish Dictionary}

Turkish Dictionary: Derivations of Turkish Languages and Literary Dictionaries, which is composed of 4 volumes textbook. This was prepared by Hüseyin Kazım Kadri and it is a product of 35 years of work. The dictionary includes 19778 main words and composed of 3659 pages. The point that distinguishes this work from others is that it includes Turkish dialects. The first two volumes of the dictionary were written with Arabic letters. Other two volumes were written with Latin letters. (Hüseyin Kazım Kadri, 1927, 1928, 1943, 1945). 
The Number of Words and Their Percentage in Excellent Ottoman Dictionary

Table 6. Numerical Distribution of Words According to Origins

\begin{tabular}{|c|c|c|c|c|}
\hline Chagatai & 4180 & Armenian & \multicolumn{2}{|c|}{33} \\
\hline Arabic & 3059 & Latin & \multicolumn{2}{|c|}{24} \\
\hline Western & 2722 & Spanish & \multicolumn{2}{|c|}{16} \\
\hline Kazan language & 2565 & German & \multicolumn{2}{|c|}{9} \\
\hline Azerbaijanis & 1801 & Uzbek & \multicolumn{2}{|c|}{9} \\
\hline Persian & 1525 & Russian & \multicolumn{2}{|c|}{9} \\
\hline Uighur & 948 & Bulgarian & \multicolumn{2}{|c|}{6} \\
\hline French & 707 & Hungarian & \multicolumn{2}{|c|}{6} \\
\hline Italian & 434 & Slavic & \multicolumn{2}{|c|}{5} \\
\hline Romaic & 282 & Chinese & \multicolumn{2}{|c|}{3} \\
\hline Unknown & 236 & Romanian & \multicolumn{2}{|c|}{3} \\
\hline Mongolian & 79 & Albanese & \multicolumn{2}{|c|}{2} \\
\hline English & 58 & Greek & \multicolumn{2}{|c|}{1} \\
\hline Kirghiz & 37 & Sanskrit & \multicolumn{2}{|c|}{1} \\
\hline Turkmen & 36 & Serbian & \multicolumn{2}{|c|}{1} \\
\hline Kashgar & 33 & Common & \multicolumn{2}{|c|}{948} \\
\hline & & Total & \multicolumn{2}{|c|}{19778} \\
\hline Chagatai & $\begin{array}{c}\text { Kazan } \\
\text { Language }\end{array}$ & Persian & Uighur & $\begin{array}{c}\text { Total of Other } \\
\text { Languages }\end{array}$ \\
\hline 4180 & 2565 & 1525 & 948 & 4399 \\
\hline$\% 17$ & $\begin{array}{cc}\% 14 & \% 10 \\
\end{array}$ & $\% 8$ & $\% 5$ & $\% 23$ \\
\hline \multicolumn{3}{|c|}{ Turkish (Asian Turkish Dialects) Originated Words } & \multicolumn{2}{|c|}{ Other Languages } \\
\hline \multicolumn{3}{|c|}{9609} & \multicolumn{2}{|c|}{9221} \\
\hline \multicolumn{3}{|c|}{$\% 51$} & \multicolumn{2}{|r|}{$\% 49$} \\
\hline
\end{tabular}

In Turkish Dictionary which is composed of 19778 main words \%23 (4180) of the words are Chagatai originated, \%17 (3059) are Arabic originated, \%14 (2565) are Kazan language originated, \%10 (1801) are Azerbaijani oriented, \%8 (1525) are Persian originated, \%5 (948) are Uyghur language and \%23 (4399) are originated from other languages. Totally, \%51 (9609) of the words in dictionary are Turkish (Central Asia Turkish Dialects) originated, and \%82 (17547) of them are originated from other languages.

\section{Great Ottoman-Turkish Dictionary}

Great Ottoman-Turkish Dictionary was prepared by Mustafa Nihat Özün who composed of 808 pages. Its first publication was made in 1952 and it was including more than 1000 words in its 5th publication (1973) (Özön, 1973).

The Number of Words and Their Percentage in Great Ottoman-Turkish Dictionary

Table 7. Numerical Distribution of Words According to Origins

\begin{tabular}{cccc}
\hline Arabic & Persian & Turkish & Total \\
\hline 17578 & 9841 & 16 & 27435 \\
\hline$\% 64$ & $\% 36$ & $\% 0$ & \\
\hline Turkish Originated Words & Words Originated from Other Languages \\
\hline 16 & $\% 100$ \\
\hline
\end{tabular}

In Great Ottoman-Turkish Dictionary which is composed of 27851 main words \%0 (16) of the words are Turkish originated, \%64 (17578) are Arabic originated, \%36 (9841) are Persian originated. Totally, \%0 (16) of the words in dictionary are Turkish originated, and \%100 (27419)of them are originated from other languages.

\section{Encyclopedic Ottoman Turkish Dictionary}

Encyclopedic Ottoman Turkish Dictionary of Ferit Develioğlu, which made 14th edition and is composed of 1195 pages includes 43048 main words (Devellioğlu, 1997).

Distribution of words according to languages, Ottoman compound words that have been formed through combining Arabic-Persian, Arabic-Turkish, Persian-Turkish, percentages of words in dictionary according to languages have been presented after being examined. 
The Number of Words and Their Percentage in Encyclopedic Ottoman Turkish Dictionary

Table 8. Numerical Distribution of Words According to Origins

\begin{tabular}{|c|c|c|c|c|c|c|}
\hline Arabic & Persian & Turkish & Greek & French & Greek & Total \\
\hline 32314 & 10462 & 263 & 5 & 3 & 1 & 43048 \\
\hline \multicolumn{7}{|c|}{ Percentages of Words } \\
\hline Arabic & & Persian & Turkish & \multicolumn{3}{|c|}{ Total of Western Languages } \\
\hline 32314 & & 10462 & 263 & \multicolumn{3}{|c|}{9} \\
\hline$\% 75$ & & $\% 24$ & $\% 1$ & \multicolumn{3}{|c|}{$\% 0$} \\
\hline \multicolumn{7}{|c|}{ Percentages of Turkish and Non-Turkish Words } \\
\hline \multicolumn{3}{|c|}{ Turkish Originated Words } & \multicolumn{4}{|c|}{ Words Originated from Other Languages } \\
\hline \multicolumn{3}{|c|}{263} & \multicolumn{4}{|c|}{42785} \\
\hline \multicolumn{3}{|c|}{$\% 1$} & \multicolumn{4}{|c|}{$\% 99$} \\
\hline
\end{tabular}

In Encyclopedic Ottoman Turkish Dictionary, which is composed of 43048 main words \%1 (263) of the words are Turkish originated, \%75 (32314) are Arabic originated, \%24 (10462) are Persian originated and $\% 0(9)$ are western originated. Totally, \%1 (263) of the words in dictionary are Turkish originated, and $\% 99$ (42785) of them are originated from other languages.

\section{Ottoman-Turkish Dictionary}

Ottoman Turkish Dictionary, which was prepared by Ali Seydi Bey consists of 736 pages and includes 18676 words (Doğan, 1995; 1999).

While preparing Ottoman-Turkish Dictionary, the author, Ahmet Doğan, criticizes the dictionaries publicated before stating that some of these works are prepared for high level of scientific researches and some others are not satisfactory in terms of usage. The dictionary was prepared with the idea that the language is a bridge linking the present to the future includes Arabic and Persian words being used in Turkish.

The Number of Words and Their Percentage in Ottoman-Turkish Dictionary

Table 9. Numerical Distribution of Words According to Origins

\begin{tabular}{|c|c|c|c|c|c|c|c|c|}
\hline Arabic & Persian & Turkish & Greek & French & Mongolian & Derived & Other & Total \\
\hline 14550 & 3490 & 147 & 4 & 3 & 1 & 1196 & 481 & 19872 \\
\hline \multicolumn{9}{|c|}{ Percentages of Words } \\
\hline & Arabic & \multicolumn{2}{|c|}{ Persian } & \multicolumn{2}{|c|}{ Turkish } & \multicolumn{3}{|c|}{ Total of Other Languages } \\
\hline & 14550 & \multicolumn{2}{|c|}{3490} & \multicolumn{2}{|c|}{147} & \multicolumn{3}{|c|}{489} \\
\hline & $\% 77$ & & & & 1 & & $\% 3$ & \\
\hline \multicolumn{9}{|c|}{ Percentages of Turkish and Non-Turkish Words } \\
\hline \multicolumn{4}{|c|}{ Turkish Originated Words } & \multicolumn{5}{|c|}{ Words Originated from Other Languages } \\
\hline \multicolumn{4}{|c|}{147} & \multicolumn{5}{|c|}{18529} \\
\hline \multicolumn{4}{|c|}{$\% 1$} & \multicolumn{5}{|c|}{$\% 99$} \\
\hline
\end{tabular}

In Ottoman-Turkish Dictionary which is composed of 18676 main words \%1 (147) of the words are Turkish originated, \%77 (14550) are Arabic originated, \%19 (3490) are Persian originated and \%3 (489) are originated from other languages. Totally, $\% 1$ (147) of the words in dictionary are Turkish originated, and $\% 99$ (18529) of them are originated from other languages. 


\section{Encyclopedic Ottoman Turkish Dictionary}

Encyclopedic Ottoman Turkish Dictionary, which was prepared by Arif Hikmet Par and consists of 530 pages includes 10585 main words (Par, 2000). In this work Arabic, Persian and Turkish words was presented.

The Number of Words and Their Percentage in Encyclopedic Ottoman Turkish Dictionary

Table 10. Numerical Distribution of Words According to Origins

\begin{tabular}{|c|c|c|c|}
\hline Arabic & Persian & Turkish & Total \\
\hline 8020 & 1773 & 792 & 10585 \\
\hline$\% 76$ & $\% 17$ & $\% 7$ & \\
\hline \multicolumn{4}{|c|}{ Percentages Of Turkish And Non-Turkish Words } \\
\hline \multicolumn{2}{|c|}{ Turkish Originated Words } & \multicolumn{2}{|c|}{ Words Originated from Other Languages } \\
\hline \multicolumn{2}{|c|}{792} & \multicolumn{2}{|c|}{9793} \\
\hline \multicolumn{2}{|c|}{$\% 7$} & \multicolumn{2}{|c|}{$\% 93$} \\
\hline
\end{tabular}

In Encyclopaedic Ottoman Turkish Dictionary, which is composed of 10585 main words \%7 (792) of the words are Turkish originated, \%76 (8020) are Arabic originated, \%17 (1773) are Persian originated. Totally, $\% 7$ (792) of the words in dictionary are Turkish originated, and \%93 (9793) of them are originated from other languages.

\section{Hayat Great Turkish Dictionary}

Hayat Great Turkish Dictionary's director of general publication is Şevket Rado, scientific controller is Muharrem Ergin and editor is Yllmaz Öztuna and this work is composed of 1288 pages and includes 25381 main words (Rado- Ergin- Öztuna, t.y.).

The Number of Words and Their Percentage in Hayat Great Turkish Dictionary

Table 11. Numerical Distribution of Words According to Origins

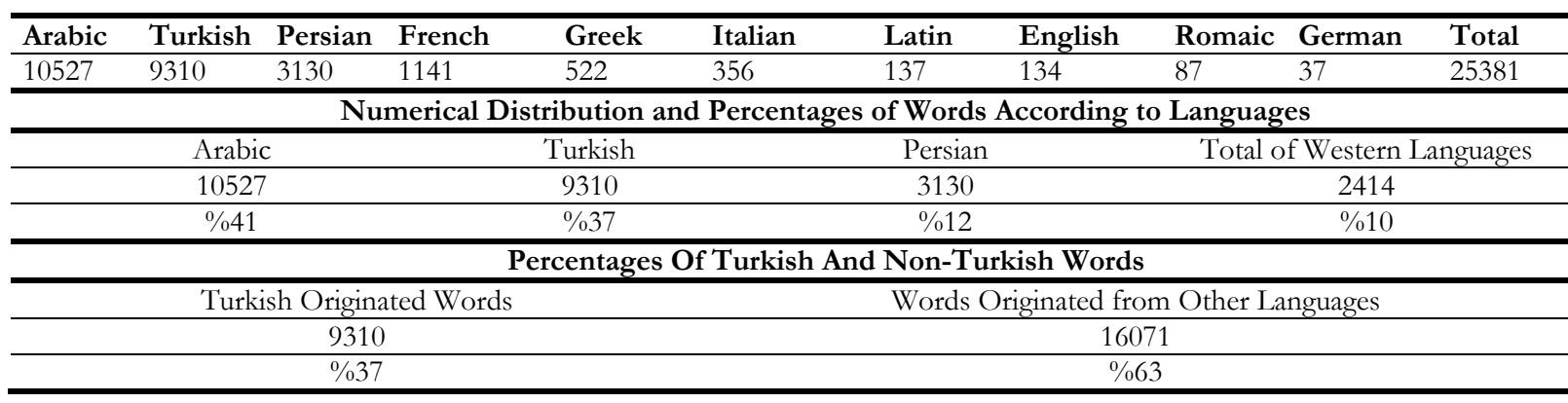

In Hayat Great Turkish Dictionary which is composed of 25381 main words \%37 (9310) of the words are Turkish originated, \%41 (10527) are Arabic originated, \%12 (3130) are Persian originated and $\% 10$ (2414) are western originated. Totally, \%37 (9310) of the words in dictionary are Turkish originated, and $\% 63$ (16071) of them are originated from other languages.

\section{Turkish Dictionary}

The 9th edition of Turkish Dictionary was prepared by Turkish Language Institute and was published in 1988 in two volumes. The dictionary was prepared by Prof. Dr. İsmail Parlatır, Prof. Dr. Nevzat Gözaydın, Prof Dr. Hazma Zülfikar, Belgin Tezcan Aksu, Seyfullah Türkmen ve Yaşar Yılmaz. In the enrichment of dictionary, primarily books of secondary education was scanned, words was collected from newspapers and journals, words used by various occupations was compiled and words widely used in Turkish was collected from glossary of terms and added Turkish Dictionary. In this work 9th edition and 1998 print of Turkish Dictionary was examined and words were analyzed. Since the main goal was the main/original words, compound words and phrases derived from these words were not taken into consideration. After the analyses, 18355 words and the languages to which these words belong was exhibited. Apart from these, the percentages of Turkish words and words coming from other languages was presented in graphics and tables below (Parlatır vd., 1988). 
The Number of Words and Their Percentage in Turkish Dictionary

Table 12. Numerical Distribution of Words According to Origins

\begin{tabular}{|c|c|c|c|c|c|c|c|c|c|c|c|c|c|c|}
\hline$\frac{0}{\frac{0}{\pi}}$ & 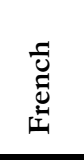 & 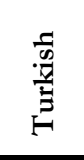 & 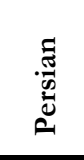 & 丞 & 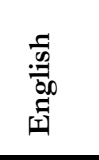 & 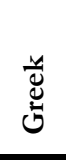 & 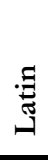 & 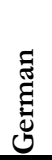 & 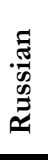 & $\begin{array}{l}\text { की } \\
\text { की } \\
\text { की }\end{array}$ & 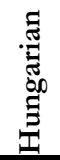 & $\frac{\sqrt{5}}{\omega}$ & 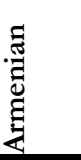 & 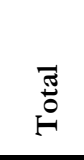 \\
\hline 6342 & 4551 & 4417 & 1366 & 580 & 415 & 370 & 87 & 84 & 34 & 34 & 18 & 16 & 14 & 18355 \\
\hline \multicolumn{15}{|c|}{ Percentages of Words } \\
\hline \multicolumn{4}{|c|}{ Arabic } & \multicolumn{3}{|c|}{ Turkish } & \multicolumn{4}{|c|}{ Persian } & \multicolumn{4}{|c|}{ Total of Western Languages } \\
\hline \multicolumn{4}{|c|}{6342} & \multicolumn{3}{|c|}{4417} & \multicolumn{4}{|c|}{1366} & \multicolumn{4}{|c|}{6230} \\
\hline \multicolumn{4}{|c|}{$\% 35$} & & $\% 24$ & & \multicolumn{4}{|c|}{$\% 7$} & \multicolumn{4}{|c|}{$\% 34$} \\
\hline \multicolumn{15}{|c|}{ Percentages of Turkish and Non-Turkish Words } \\
\hline \multicolumn{7}{|c|}{ Turkish Originated Words } & \multicolumn{8}{|c|}{ Words Originated from Other Languages } \\
\hline \multicolumn{7}{|c|}{4417} & \multicolumn{8}{|c|}{13938} \\
\hline \multicolumn{7}{|c|}{$\% 24$} & \multicolumn{8}{|c|}{$\% 76$} \\
\hline
\end{tabular}

In Turkish Dictionary, which is composed of 18355 main words \%24 (4417) of the words are Turkish originated, \%35 (6342) are Arabic originated, \%7 (1366) are Persian originated and \%34 (6230) are western originated. Totally, \%24 (4417) of the words in dictionary are Turkish originated, and \%76 (13938) of them are originated from other languages.

\section{New Turkish Dictionary}

Mehmet Bahaettin Toven's New Turkish Dictionary is composed of 1210 pages. From 822nd page, the index part of the dictionary starts. In the dictionary there are totally 18782 main words (Toven, 2004).

The Number of Words and Their Percentage in New Turkish Dictionary

Table 13. Numerical Distribution of Words According to Origins

\begin{tabular}{|c|c|c|c|c|c|c|c|c|c|c|}
\hline Arabic & Turkish & Persian & French & Italian & English & Greek & German & Spanish & $\begin{array}{c}\text { Other Foreign } \\
\text { Language }\end{array}$ & Total \\
\hline 9997 & 5386 & 1866 & 84 & 65 & 61 & 21 & 4 & 4 & 1294 & 18782 \\
\hline \multicolumn{11}{|c|}{ Percentages Of Words } \\
\hline \multicolumn{2}{|r|}{ Arabic } & \multicolumn{3}{|c|}{ Turkish } & \multicolumn{3}{|c|}{ Persian } & & \multicolumn{2}{|c|}{ Total of Western Languages } \\
\hline \multicolumn{2}{|r|}{9997} & \multicolumn{3}{|c|}{5386} & \multicolumn{3}{|c|}{1866} & & \multicolumn{2}{|l|}{1533} \\
\hline & $\% 53$ & & $\% 29$ & & & $\% 1$ & & & $\% 8$ & \\
\hline \multicolumn{11}{|c|}{ Percentages of Turkish and Non-Turkish Words } \\
\hline \multicolumn{4}{|c|}{ Turkish Originated Words } & \multicolumn{7}{|c|}{ Words Originated from Other Languages } \\
\hline \multicolumn{4}{|c|}{5386} & \multicolumn{7}{|c|}{\begin{tabular}{|cccc} 
& 13396 & 0 \\
\end{tabular}} \\
\hline \multicolumn{4}{|c|}{$\% 29$} & \multicolumn{7}{|c|}{$\% 71$} \\
\hline
\end{tabular}

In New Turkish Dictionary which is composed of 18782 main words \%29 (5386) of the words are Turkish originated, \%53 (9997) are Arabic originated, \%10 (1866) are Persian originated and \%8 (1533) are western originated. Totally, $\% 29$ (5386) of the words in dictionary are Turkish originated, and \%71 (13396) of them are originated from other languages.

\section{Great Turkish Dictionary}

Great Turkish Dictionary was published firstly in 1981 and after four publication made between 1981 and 1986, extended fifth edition was made. The publications between the fifth and ninth are the same of the text in fifth edition. The dictionary, which was examined is the tenth edition. The dictionary is composed of 1169 pages and includes 44195 main words and when the compound words added, the number of words reaches to 52997 (Doğan, 1996). 
The Number of Words and Their Percentage in Great Turkish Dictionary

Table 14. Numerical Distribution of Words According to Origins

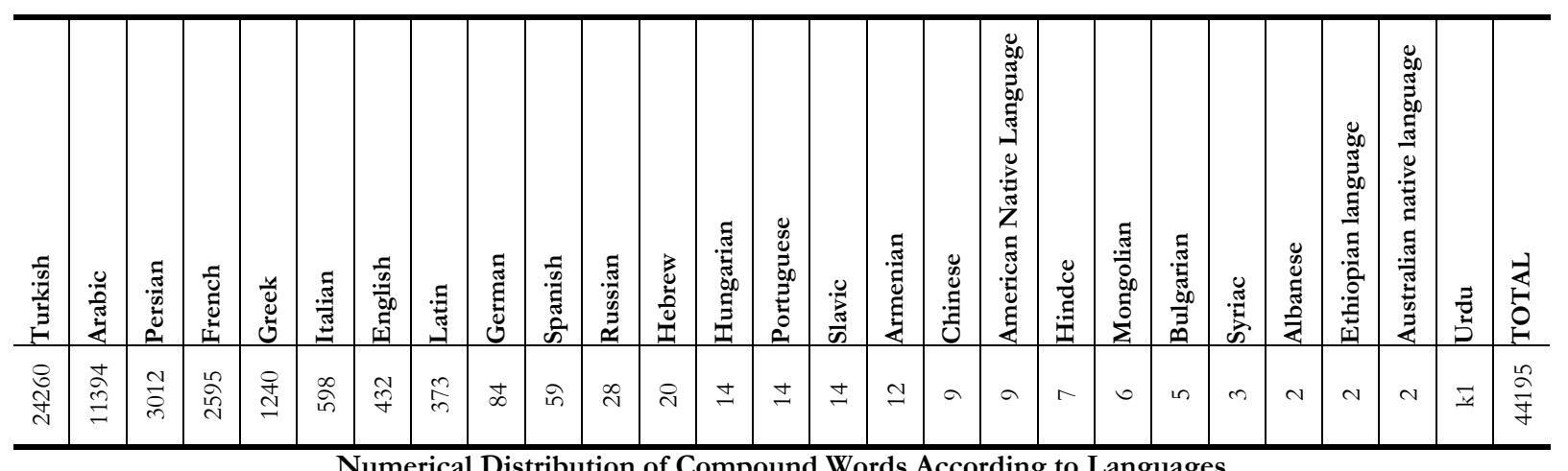

Numerical Distribution of Compound Words According to Languages

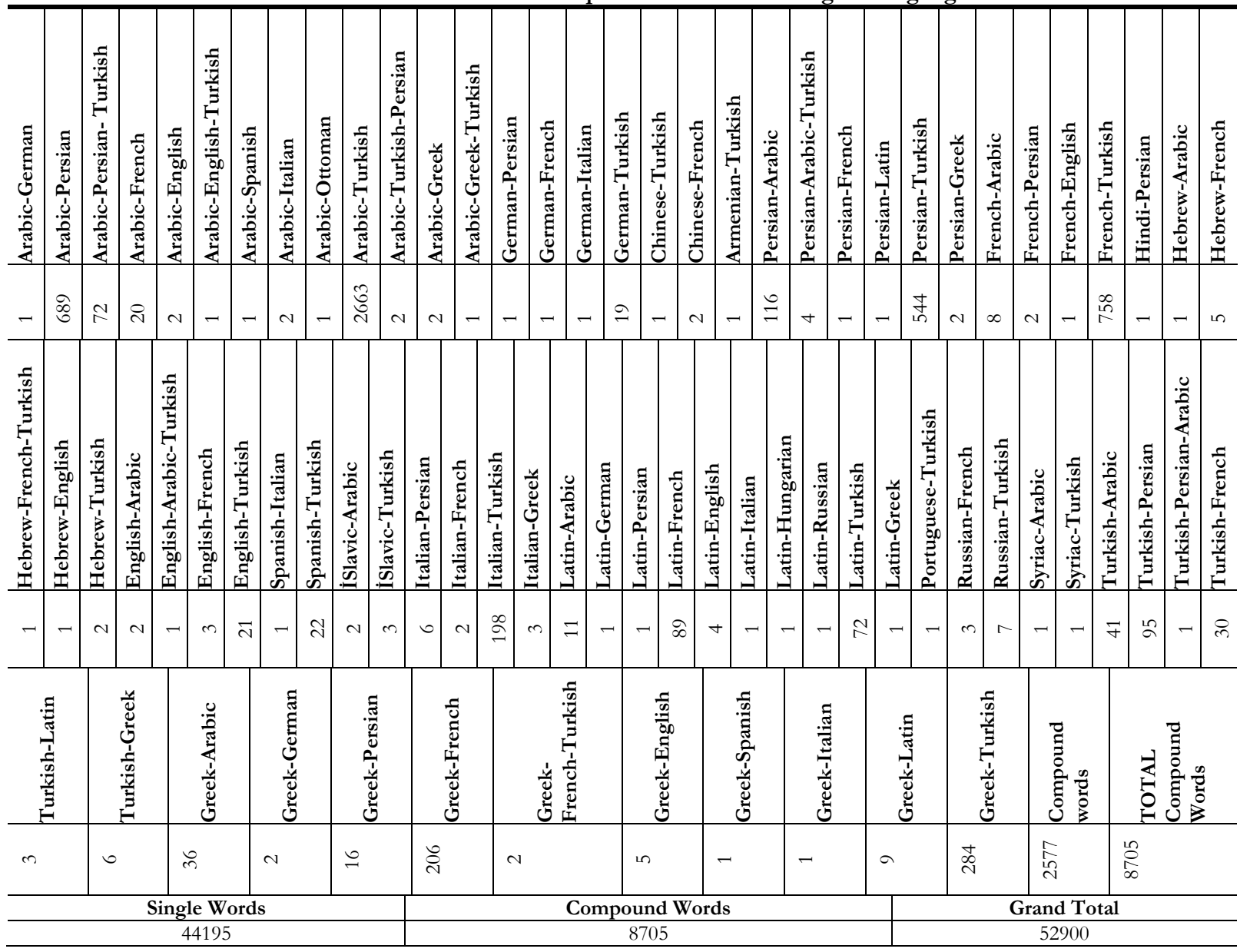


Table 15. Numerical Distribution of All Words According to Origins

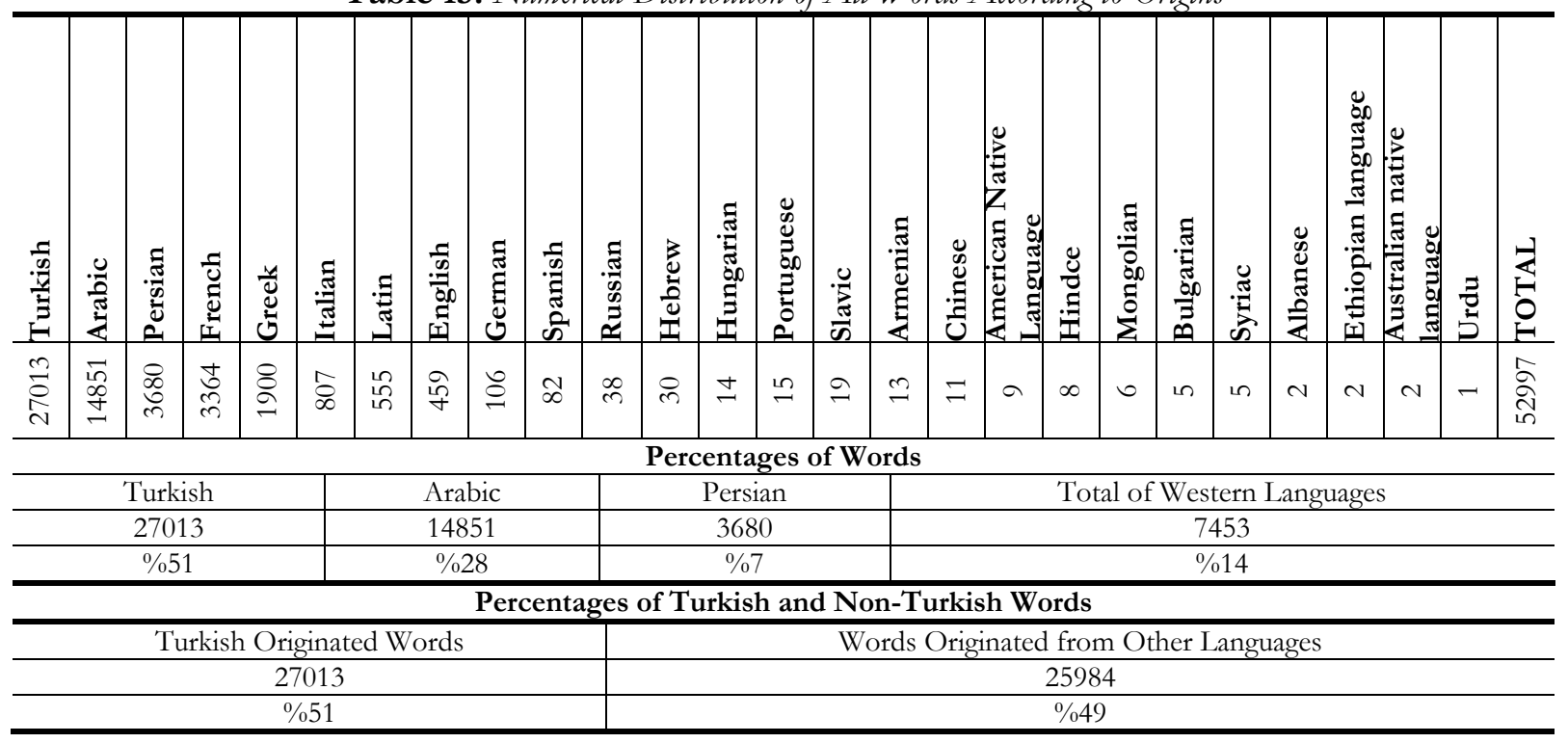

In Great Turkish Dictionary, which is composed of 52997 main words \%51 (27013) of the words are Turkish originated, \%28 (14851) are Arabic originated, \%7 (3680) are Persian originated and \%14 (7453) are western originated. Totally, \%51 (27013) of the words in dictionary are Turkish originated, and \%49 (25984) of them are originated from other languages.

\section{Exampled Great Turkish Dictionary}

Exampled Great Turkish Dictionary in the Historical Course of Centuries, which was published in 2005 , is a 3 volumed Turkish dictionary put forward after 34 years of work. The dictionary is composed of 3520 pages includes 46035 main words. (Ayverdi vd., 2006).

This is "a reference book with 100 thousand examples, which is prepared through scanning 61 thousand main and secondary entries, approximately 35 thousand expressions, about 1000 works of 400 writers". The advisory board which started to work firstly in 1971-1972 at the language academy that was actuated by Kubbealtı Foundation which was founded by Samiha Ayverdi, İlhan Ayverdi, Ekrem Hakk1 Ayverdi, Nihad Sami Banarlı in 1972 with a commision of 11 people who have studied on Turkish language was consisting of Samiha Ayverdi (1905-1993), Dr. Ekrem Hakk1 Ayverdi (1899-1984), Nihad Sami Banarlı (1907-1974), Tahsin Banguoğlu (1904-1989), Ömer Lütfi Barkan (1902-1979), Kaya Bilgegil (1921-1987), Abdülkadir İnan (1889-1976), Faruk Kadri Timurtaş (1925-1982), Faruk Nafiz Çamlıbel (1898-1973), Orhan Seyfi Orhon (1890-1972), Fevziye Abdullah Tansel (1912-1988). The dictionary was started to be written in 1976 and Illhan Ayverdi took the leadership of the Academy, which was separated after a long period of work. Then, Marmara University also participated into this dictionary labor. Eventually, Kubbealtı Dictionary/ Great Turkish Dictionary with Examples" was completed in 2005 after a work of 34 years through scanning Turkish works from 13th century to 20th century. (Ayverdi vd., 2006).

The name which is seen in the first page of dictionary are: İlhan Ayverdi, Ahmet Topaloğlu, Hayri Bilecik, Mustafa Tahralı, Fahrünnisa Bilecik, Hülya Uğur. (Ayverdi vd., 2006).

Etymological editorial of Exampled Great Turkish Dictionary in the Historical Course of Centuries was conducted by Prof. Dr. Ahmet Topaloğlu. Etymological and orthographical editors for Arabic and Persian elements were Prof. Dr. Mustafa Tahralı ve Hayri Bilecik. Many scholars and ideologists served for areas that necessitate expertise such as: Prof. Dr. Kenan Gürsoy (Philosophy), Prof. Dr. Tarık Akçal (Medicine), Prof. Dr. Mustafa Fayda (Theology), Prof. Dr. Fahreddin Olguner (Philosophy of Islam), Prof. Honoris Causa Uğur Derman (Decoration Arts) ve Prof. Dr. Muhittin Serin (Calligraphy). (Ayverdi vd., 2006). 
BIYIKLI

Turkish Glossary Production and Meaning in the Inherit of Turkish Culture: Comparative Analysis of Seventeen Turkish Language Dictionaries

The Number of Words and Their Percentage in Exampled Great Turkish Dictionary

Table 16. Numerical Distribution of Words According to Origins

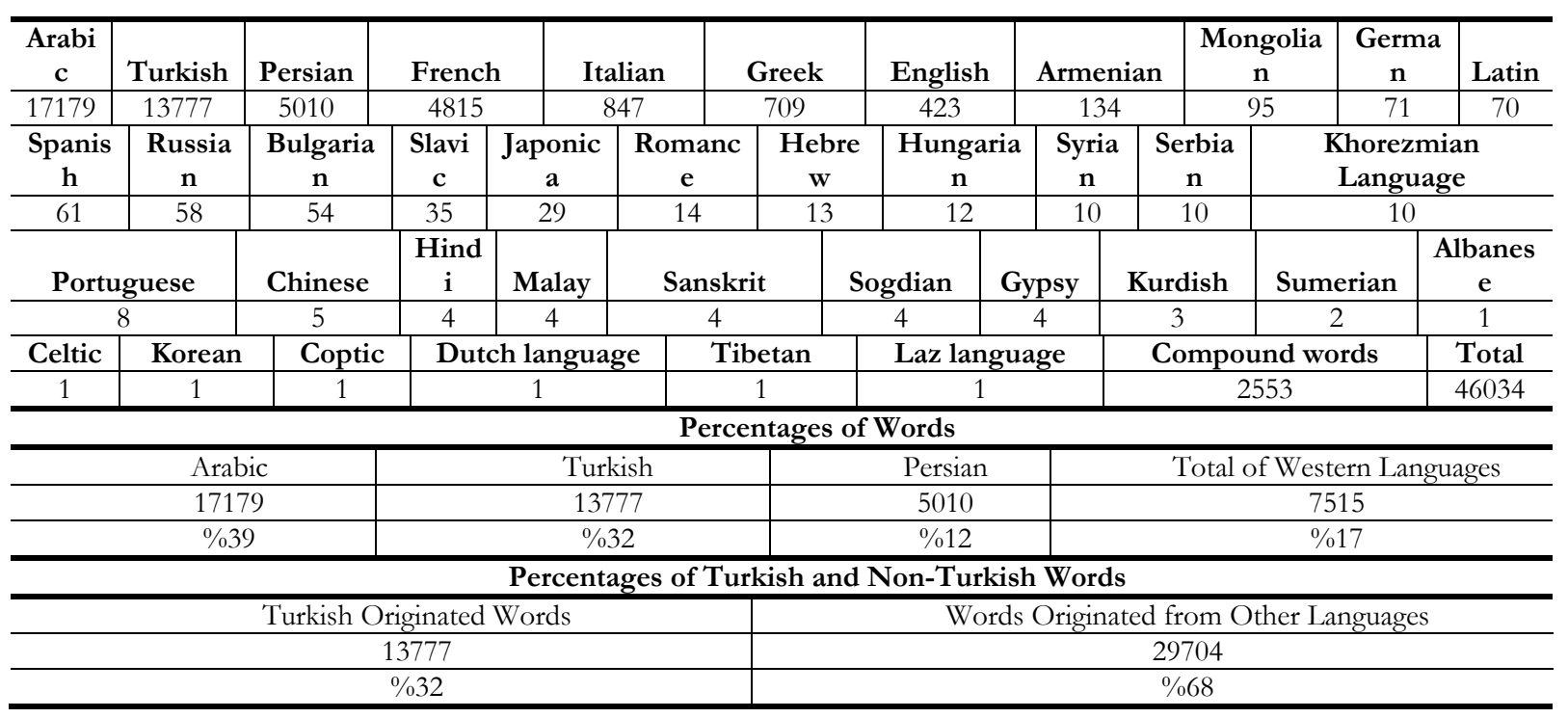

In Exampled Great Turkish Dictionary, which is composed of 46035 main words \%32 (13777) of the words are Turkish originated, \%39 (17179) are Arabic originated, \%12 (5010) are Persian originated and $\% 17$ (7516) are western originated. Totally, \%32 (13777) of the words in dictionary are Turkish originated, and $\% 68$ (29705) of them are originated from other languages.

\section{Turkish Dictionary with Examples}

The first edition of Turkish Dictionary with Examples was prepared by a commission formed by Ministry of Education from lecturers and Turkish language and literature teachers was made in 1995. The edition was examined is the 4th edition that was published in 2004. Turkish Dictionary with Examples which is composed of 4 volumes and 2406 pages includes 39533 words (Komisyon, 2004).

The Number of Words and Their Percentage in Turkish Dictionary with Examples

Table 17. Numerical Distribution of Words According to Origins

\begin{tabular}{|c|c|c|c|c|c|c|c|c|c|c|c|c|c|c|c|}
\hline 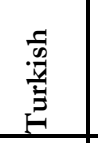 & $\begin{array}{l}0 \\
\frac{\pi}{\pi}\end{array}$ & $\begin{array}{l}\tilde{0} \\
\text { E. } \\
\text { D. } \\
\end{array}$ & 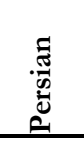 & 芶 & 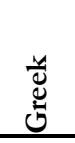 & 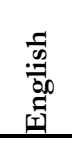 & 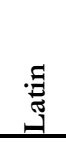 & 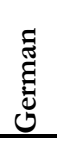 & 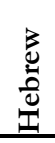 & $\begin{array}{l}\frac{\pi}{0} \\
\text { है } \\
\text { की }\end{array}$ & 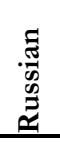 & $\frac{\sqrt{5}}{\frac{5}{\omega}}$ & 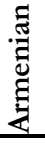 & 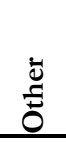 & 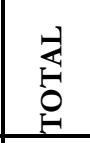 \\
\hline 23553 & 7616 & 3845 & 2823 & 543 & 411 & 340 & 141 & 52 & 50 & 34 & 20 & 13 & 8 & 402 & 39533 \\
\hline \multicolumn{16}{|c|}{ Percentages of Words } \\
\hline \multicolumn{2}{|l|}{ Turkish } & \multicolumn{2}{|l|}{ Arabic } & \multicolumn{2}{|c|}{ French } & \multicolumn{2}{|c|}{ Persian } & \multicolumn{2}{|c|}{ Italian } & \multicolumn{2}{|c|}{ Greek } & \multicolumn{2}{|c|}{ English } & \multicolumn{2}{|c|}{ Other } \\
\hline \multicolumn{2}{|l|}{23553} & \multicolumn{2}{|l|}{7616} & \multicolumn{2}{|c|}{3845} & \multicolumn{2}{|c|}{2823} & \multicolumn{2}{|c|}{543} & \multicolumn{2}{|c|}{411} & \multicolumn{2}{|c|}{340} & \multicolumn{2}{|c|}{402} \\
\hline \multicolumn{2}{|l|}{$\% 60$} & \multicolumn{2}{|l|}{$\% 19$} & \multicolumn{2}{|c|}{$\% 10$} & \multicolumn{2}{|c|}{$\% 7$} & \multicolumn{2}{|c|}{$\% 1$} & \multicolumn{2}{|c|}{$\% 1$} & \multicolumn{2}{|c|}{$\% 1$} & \multicolumn{2}{|c|}{$\% 1$} \\
\hline \multicolumn{16}{|c|}{ Percentages of Turkish and Non-Turkish Words } \\
\hline \multicolumn{4}{|c|}{ Turkish } & \multicolumn{12}{|c|}{$\begin{array}{lr} & \text { Other Languages } \\
\end{array}$} \\
\hline \multicolumn{4}{|c|}{23553} & \multicolumn{12}{|c|}{15980} \\
\hline \multicolumn{4}{|c|}{$\% 60$} & \multicolumn{12}{|c|}{$\% 40$} \\
\hline
\end{tabular}

In Turkish Dictionary with Examples which is composed of 39533 main words \%60 (23553) of the words are Turkish originated, \%19 (7616) are Arabic originated, \%10 (3845) are French oriented, \%7 (2823) Persian oriented, \%1 (543) Italian oriented, \%1 (411) Greek oriented, \%1 (340) are English oriented and \%1 (402) are originated from other languages. Totally, \%60 (23553) of the words in dictionary are Turkish originated, and \%40 (15980) of them are originated from other languages. 


\section{Ötüken Turkish Dictionary}

Ötüken Turkish Dictionary, Vocabulary of Turkish of Turkey from Orhun Inscriptions to Present was completed in 2006 after a 38 years of work. The dictionary is composed of 5 volumes was published by Ötüken Publications in 2007. Ötüken Turkish Dictionary is composed of 5509 pages and includes 163953 words (Çağbayır, 2007).

The Number of Words and Their Percentage in Ötüken Turkish Dictionary

Table 18. Numerical Distribution of Words According to Origins

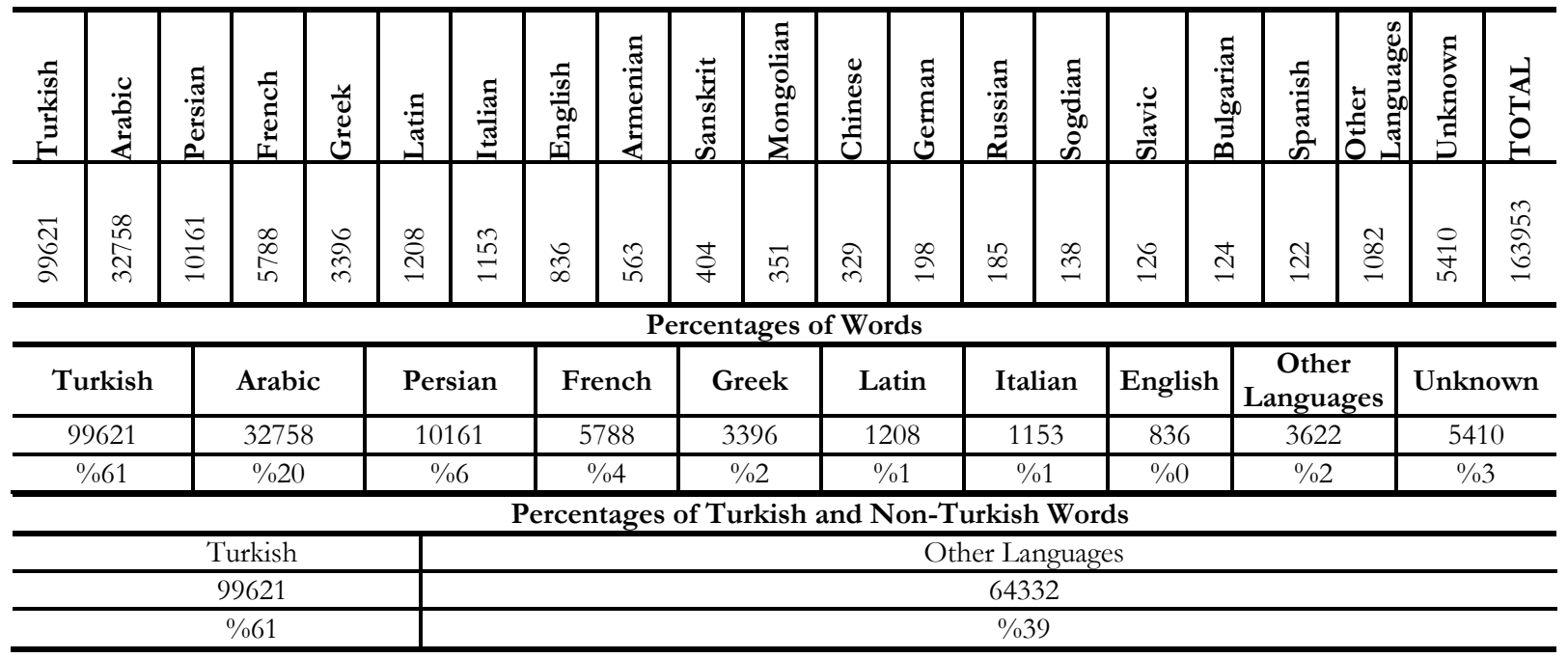

In Ötüken Turkish Dictionary which is composed of 163953 main words \%61 (99621) of the words are Turkish originated, \%20 (32758) are Arabic originated, \%4 (5788) are French oriented, \%6 (10161) Persian oriented, \%1 (1153) Italian oriented, \%2 (3396) Greek oriented, \%1 (1208) are Latin oriented, \%0 (836) are English oriented and \%2 (3622) are originated from other languages. The origins of \%3 (5410) of the words are not known. Totally, \%61 (99621) of the words in dictionary are Turkish originated, and $\% 39$ (64332) of them are originated from other languages.

\section{Conclusion}

The percentages of the origins of words in Ottoman dictionaries (totally 10 dictionaries) are: 13\% Turkish, $62 \%$ Arabic, 21\% Persian and 4\% western languages.

The percentages of origins of Turkish words and the words originated from other languages in Ottoman dictionaries (totally 10 dictionaries) are: 13\% Turkish, 87\% other languages.

The percentages of origins of words in Turkish dictionaries (totally 7 dictionaries) are: 51\% Turkish, 28\% Arabic, 8\% Persian, 7\% French, 2\% Greek, 1\% Italian, 1\% English and 2\% from other languages.

The percentages of origins of Turkish words and the words originated from other languages in Turkish dictionaries (totally 7 dictionaries) are: 51\% Turkish, 49\% other languages.

The percentages of Turkish originated words and the words originated from other languages in all Ottoman and Turkish dictionaries (totally 17 dictionaries) are: 36\% Turkish, 64\% other languages.

In this work, we presented and compared, in tables, the numbers of Turkish words and words that have entered to Ottoman-Turkish dictionaries/glossaries from other languages after being used and processed throughout centuries according to their origins and exhibited with tables and graphics the percentages of Turkish original words and words originated from other languages.

It is possible to conclude from these examinations, tables and observations in graphics that: it is natural and inevitable that languages interact from each other as a result of relation, communication and influence between civilizations and cultures living together or in close geographies throughout the centuries. 
The process of Turkish-Arabic alliance which started in 751, Turkish entrance to Middle-East, 1000 years of Turkish government and domination in Arab world that started with Tulunids, Seljuk domination on Persians and 400 years of Ottoman domination on Arabs have to be taken into consideration.

Middle East which is an intersection point of Mediterranean basin and seas, a crib for civilizations and cultures and a geo-cultural center for especially for Islamic world has been the center of cultural interaction of states and nations under Turkish domination and influence area. Thus, it is natural to see the percentages of Arabic and Persian words higher in dictionaries, since these two cultures influences these periods as a result of Ottoman sovereignty.

Starting from the Tanzimat Period and throughout the 20th century, the discussions, purification efforts on Turkish and the efforts of elimination of the Arabic, Persian words and words that originates from other languages, cultures and have transformed into Turkish, from Turkish language caused a significant gap in Turkish.

However, words coming intensely from western languages have filled and are going on filling this gap of word in Turkish language and dictionary. When we look at the tables we observe that this gap is being filled by mostly French words and by the words that have not been adapted into Turkish. Greek, Latin, Italian and English follow that language.

Deliberately or not, all the Arabic and Persian words have been eliminated from the books published by Turkish Ministry of Education of last years. This brought about the result that new generation can not understand not only Ottoman books but also the Turkish books written in the first quarter of 20th century and even the works published after that period. Ottoman culture has been obliterated from the last generation. Terms, concepts and images have been erased from the minds. The new generation cannot understand even the common Ottoman words. And this separates the new generation from historical, cultural treasure and national values.

Words, therefore glossaries, dictionaries are the memories, identities, vocabularies and culture treasures, accumulations of nations. Great thinkers, scientists, scholars, inventers come from the languages which have rich vocabularies, wide accumulations.

Language is the identity of a nation, the source of word and culture treasure. The scientific and intellectual life comes up with language. The nations, which have ensured the unity and integrity of themselves are the ones which have unity of language and integrity of words.

Turkish, which is a social and national memory, institution and at the same time a living thing and the identity of Turks has, naturally, been effected from other languages, cultures as a result of affections among nations and cultures. Turkish has, consciously or unconsciously, been effected as international lecture books, scientific, ideological and philosophical works have been translated, literature, economy, innovations, technology and communication have been advanced throughout the centuries in an intensifying mode. Turkish language, which has phrases with historical backgrounds, is a meaning, sense, expression and image that has originated in the minds of generations in the lands in which Turks have been dominant and sovereign. this.

It would be proper to keep the missionary approaches, pressures and interventions to language out of

It would be the most proper to generate ideas to protect Turkish language instead of eliminating the words coming from other languages from Turkish which has been enriched with the words that have transformed into Turkish after being used throughout centuries.

\section{Ethical Declaration}

In the writing process of the study titled "Turkish Glossary Production and Meaning in the Inherit of Turkish Culture: Comparative Analysis of Seventeen Turkish Language Dictionaries", there were followed the scientific, ethical and the citation rules; was not made any falsification on the collected data and this study was not sent to any other academic media for evaluation. 


\section{References}

Ahmet Rasim. (t.y..). Mükemmel Kamus-ı Osmanî, Dersaadet. / Ahmet Rasim. (n.d..). Excellent Ottoman Dictionary, Dersaadet.

Ali Nazîma-Reşâd. (1319). Mükemmel Osmanlı Lügâti, Dersaadet. Hac1 Hüseyin Efendi Matbaas1, / Ali Nazîma-Reşâd. (1319). Excellent Ottoman Dictionary, Hac1 Hüseyin Efendi Printing House, Dersaadet.

Ali Seydî. (1908). Resimli Kamus-ı Osmanî, Dar'ül-Hilafet'il-Aliyye, Matbaa ve Kütüphane-i Cihan. / Ali Seydî 1908. Illustrated Ottoman Dictionary, Cihan Press House and Library, Supreme Court of Caliph.

Ayverdi, İ. (2006). Misalli Büyük Türkşe Sözlük, C:I-III, 2. Bask1, İstanbul. Kubbealtı Neşriyat. / Ayverdi, İ. (2006). Exampled Great Turkish Dictionary, C:I-III, 2nd Edition, İstanbul. Kubbealt1 Publications.

Bıyıklı, M. (2011). "Osmanlıca Açısından Arap Harfli Ve Latin Harfli Türkçe Lügatlerde ve Sözlüklerde Kelimelerin Karşılaştırmalı Analizleri", 38. ICANAS (Uluslararası Asya ve Kuzey Afrika Calışmalar Kongresi), Ankara,10-15 Eylül 2007, Bildiriler, Dil Bilimi, Dil Bilgisi ve Dil Ë̆̈timi, I. Cilt, AKDTYK, Ankara. ss. 265-289.

Biylkl, M. (2015). "Our Glossary/Word Heritage in The International Domain”, Contemporary Issues in Cultural Stadies, Editors: Maciej Kolodziejski, Mehmet Ali Icbay, Hasan Arslan, Ehrmann Verlag. Mannheim Germany. pp.: 2536.

Bıyıklı, M. (2016). “Asya-Avrupa İpek Yolunda Uluslararası Kültürel Etkileşimlerin Türkçe Lügatlerdeki Yansıması (Türk Lügâti ve Ötüken Türkçe Sözlük Örneği)”, IV. Eurasian Forum of Social Sciences/ IV. Avrasya Sosyal Bilimler Forumu, 21-22 Nisan, Kırgızistan Türkiye Manas Üniversitesi, Bişkek. Kırg1zistan.

Çağbayır, Y. (2007). Ötüken Türkşe Sözlïk, C: I-V, İstanbul. Ötüken Neşriyat. / Çağbayır, Y. 2007. Ötüken Turkish Dictionary, C: I-V, İstanbul. Ötüken Publications.

Devellioğlu, F. (1997). Osmanlica- Türkşe Ansiklopedik Lügât, 14. baskı, Ankara. Aydın Kitabevi Yayınları. / Devellioğlu, F. (1997). Ferit, Encyclopaedic Ottoman Turkish Dictionary, 14th Edition, Ankara. Aydın Bookstore Publications.

Doğan, A. (1995, 1999). Osmanlıca Türkege Sözlük, Ankara. Akçă̆ Yayınları. / Doğan, A. (1995, 1999). Ottoman-Turkısh Dictionary, Ankara. Akçağ Publications.

Doğan, D. M. (1996). Büyük Türkşe Sözlük, 11. baskı, İstanbul. İz Yayıncıllk / Doğan, D. M. (1996). Great Turkish Dictionary, 11st edition, İstanbul. İz Publications.

Hüseyin Kazım Kadri. (1943, 1945(. Türk Lügâti: Türk Dillerinin İstikakè ve Edeb̂̂ Lügâtleri, C:I-IV (C:I, 1927, C:II, 1928, C:III, 1943, C:IV, 1945), İstanbul. Devlet Matbaası. / Hüseyin Kazım Kadri. (1943, 1945). Turkish Dictionary: Derivations of Turkish Languages and Literary Dictionaries, C:I-IV, State Printing House, İstanbul, C:I, 1927, C:II, 1928, C:III, 1943, C:IV, 1945.

Komisyon. (2004). Örnekleriyle Türkşe Sö̊lük, C:I-IV, 4. Bask1, İstanbul. Milli Eğitim Bakanlığ1 Yayınları. / Commission. (2004). Turkish Dictionary with Examples, C:I-IV, 4th Edition, İstanbul. Ministry of Education Publications.

Muallim Naci. (1987). Lügât-ı Naci, İstanbul. Çağrı Yayınları / Muallim Naci. (1987). Dictionary of Naci, İstanbul. Çağrı Publications.

Özön, M. N. (1962). Türkese Yabancı Kelimeler Sözlügü, İstanbul. İnkılap ve Aka Yayınları. / Özön, M. N. (1962). Turkish Foreign Words Dictionary, İstanbul. Ink1lap ve Aka Publications, İstanbul.

Özön, M. N. (1973). Büyü̈k Osmanlica-Türkege Söəlüke, 5. Bask1, İstanbul. İnk1lap ve Aka Yayınlar1 / Özön, M. N. (1973). Great Ottoman-Turkish Dictionary, 5th Edition, İstanbul. Ink1lap ve Aka Publications.

Par, A. H. (2000). Osmanlica Türkese Ansiklopedik Sözlük, İstanbul. Serhat Yayınları. / Par, A. H. (2000). Encyclopaedic Ottoman Turkish Dictionary, İstanbul. Serhat Publications.

Parlatır, İ. vd. (1998). Türkẹe Sö̊lïk, C:I-II, 8. bask1, Ankara. Türk Dil Kurumu Yayınları. / Parlatır, İ. vd. (1998). Turkish Dictionary, C:I-II, 8th edition, Ankara. Turkish Language Institude Publications, (1998).

Rado, Ş. - Ergin, M.- Öztuna, Y. (t.y.). Hayat Büyük Türk Söəlüğ̈̈, İstanbul. Hayat Yayınları. / Rado, Ş. - Ergin, M.Öztuna, Y. (n.d.). Hayat Great Turkish Dictionary, İstanbul. Hayat Publications.

Şemseddin Sami. (1901). Kamus-ı Türkî, Dersaâdet. İkdam Matbaası / Şemseddin Sami. (1901). Turkish Dictionary, Dersaâdet. İkdam Printing House.

Toven, M. B. (2004). Yeni Türkşe Lügât, Haz. Abdülkadir Hayber, Ankara. Türk Dil Kurumu Yayınları. / Toven, M. B. (2004). New Turkish Dictionary, Prep. Abdülkadir Hayber, Ankara. Turkish Language Institute Publications.

\section{TÜRKÇE GENİ̧̧ ÖZET}

Bu çalışmada Türkçe kökenli kelimeleri ve asırlar boyu işlenerek ve kullanılarak Osmanlıca-Türkçe lügâtlere/sözlüklere girmiş kelimeleri kökenlerine göre tablolarda sayılarını ortaya koyduk, karşılaştırdık ve Türk dilinde Türkçe kökenli kelimelerle, diğer kelimelerin nisbetlerini/oranlarını tablolar ve grafikler halinde gösterdik.

Görüldüğ̈̈ gibi Osmanlıca lügâtlerdeki(10 adet) toplam kelimelerin kökenlerinin yüzdelik dağılımı şöyledir: \%13 Türkçe, $\% 62$ Arapça, $\% 21$ Farsça ve $\% 4$ Batı dilleri.

Osmanlıca lügâtlerdeki(10 adet) Türkçe ve diğer kelimelerin kökenlerinin yüzdesi şöyledir: \%13 Türkçe, $\% 87$ diğer diller. 
Türkçe sözlüklerdeki (7 adet) kelimelerin kökenlerinin yüzdelik dağılımı şöyledir: \%51 Türkçe, \%28 Arapça, \%8 Farsça, \%7 Fransızca, \%2 Yunanca, \%1 İtalyanca, \%1 İngilizce ve \%2 diğer yabanc1 diller.

Türkçe sözlüklerdeki(7 adet) Türkçe ve diğer kelimelerin kökenlerinin ortalama yüzdesi şöyledir: \%51 Türkçe, $\% 49$ diğer diller.

Tüm Osmanlıca lügâtler ve Türkçe sözlüklerdeki(17 adet) Türkçe ve diğer diller kökenlerinin toplam ortalama yüzdesi ise şöyledir: $\% 36$ Türkçe, $\% 64$ diğer diller.

Bu inceleme, tablolar, grafiklerdeki gözlemlerden şunu çıkarmak mümkündür: Asırlar boyu, ortak ve yakın coğrafyalarda medeniyetler arası, kültürler arası ilişki, iletişim ve etki sonucu dillerin birbirlerinden etkilenmesi doğal ve kaçınılmazdır.

751 yllında başlayan Türk-Arap ittifakı süreci, Türklerin Ortadoğu'ya inmeleri, Arap âleminde Tolunoğullarıyla başlayan 1000 yılllk Türk idare ve hâkimiyeti; Farslar üzerinde Selçuklu, Araplar üzerinde 400 yıllık Osmanlı hâkimiyeti dikkatlerden kaçmamalıdır. Akdeniz havzası, denizler kavşağı, kültürler, medeniyetler beşiği ve özellikle İslâm dünyasının Jeo-kültürel merkezi mahiyetindeki Ortadoğu, 400 yll Türklerin hâkimiyetinde ve Türk nüfuz sahası sınırları içinde olarak, dünya devlet ve milletlerinin kültürel etkileşim merkezi olmuştur. Dolayısıyla Selçuklu ve Osmanlı hâkimiyet süreci sonucu bu dönemleri kapsayan Arapça ve Farsça'nın yüzdelik oranlarının lügatlerde öne çıkması doğal bir birikim olarak karşımıza çıkmaktadır.

Tanzimat akımıyla başlayan ve 20. yüzyıl boyunca devam eden, Türk dili ve lügâti üzerindeki tartışmalar, Türk dilini sadeleştirme ve Türk dilinden diğer dillerden ve kültürlerden gelen Türkçeleşmiş bütün Arapça, Farsça diğer diller kökenli kelimeleri tasfiye etme gayretleri, Türkçede ve Türkçe lügâtlerde önemli bir boşluk oluşturmuştur. Ne var ki Türk dili ve lügâtinde oluşan bu kelime boşluğunu, Batı dillerinden yoğun bir şekilde gelen kelimeler bilinçli veya bilinçsiz bir şekilde doldurmuş ve doldurmaya devam etmektedir. Tablo ve grafiklere baktığımızda bu boşluğun daha çok Fransızca kelimeler ve Türkçeleşmemiş kelimelerle dolduğu gerçeği karşımıza çıkmaktadır. Bunu Yunanca, Latince, İtalyanca ve İngilizce takip etmektedir.

Kelimeler, dolayısıyla lügâtler/sözlükler, bir milletin dağarcığıdır, hafızasıdır, kelime hazinesidir, kelime ve kültür mirasıdır, dil zenginliği ve birikimidir. Büyük mütefekkirler, düşünürler, âlimler, bilginler ve mucitler, zengin kelime hazinesine, birikimine sahip dillerden çıkmıstır.

Dil, bir milletin kimliğidir, kelime ve kültür hazinesinin temeli ve kaynağıdır. Dil ile birlikte ilim ve fikir hayatı da oluşur. Dil birliğine ve kelime bütünlügüne sahip milletler, millî birlik ve bütünlüklerini de sağlayan milletler olmuşlardır.

Toplumsal ve millî bir hafıza, müessese, aynı zamanda yaşayan bir varlık ve Türklerin kimliği olan Türkçe, asırlar boyu medeniyetler arası, milletler arası ve kültürler arası tesirler sonucu tabiî olarak diğer dillerden ve kültürlerden etkilenmiştir. Milletlerarası ders kitapları, ilmî, fikrî ve felsefi eserlerin tercüme edilmesi, edebiyatın, iktisadın, icatların, teknolojinin ve iletişimin asırlar boyu yoğunlaşan bir şekilde günümüze değin gelişmesi nispetinde Türkçe de bilinçli veya bilinçsiz bir şekilde etkilenmiştir. Her kelimesi ve deyimi arkasında bir tarih yaşayan Türkçe, Türklerin hâkimiyet kurduğu ve nüfuzu altına aldığ1 sahalarda asırlar içinde ve nesillerin hafizasında yoğrula yoğrula yerleşmiş bir mana, his, ifade ve hayal halini almıştır.

Asırlar boyu kullanılarak Türkçeleşmiş kelimelerle zenginleşmiş, milli hafıza haline gelmiş lügatlerimizi ve dolayısıyla Türkçe'deki diğer diller kökenli kazanılmış kelimeleri korumak, kullanmak ve yaşatmak, zenginleşmiş Türkçeyi, öncelikle Türk Dünyası kültür havzasında bölgesel bir dil haline getirme yolunda isabetli olacaktır. 